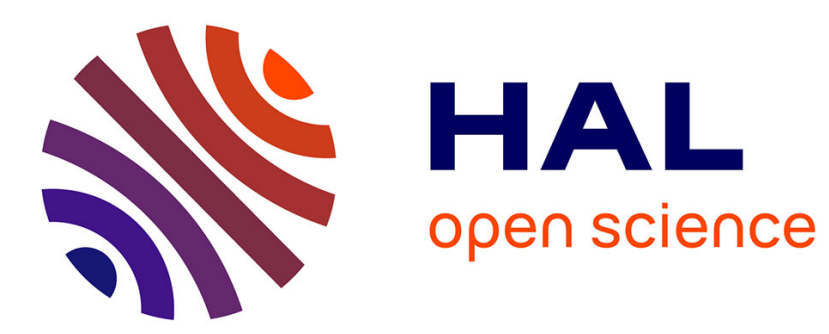

\title{
Influence of the oxyanion nature of the electrolyte on the corrosion/passivation behaviour of nickel
}

\author{
Jean-Luc Trompette, Laurent Massot, Hugues Vergnes
}

\section{To cite this version:}

Jean-Luc Trompette, Laurent Massot, Hugues Vergnes. Influence of the oxyanion nature of the electrolyte on the corrosion/passivation behaviour of nickel. Corrosion Science, 2013, vol. 74, pp. 187-193. 10.1016/j.corsci.2013.04.042 . hal-00875485

\section{HAL Id: hal-00875485 \\ https://hal.science/hal-00875485}

Submitted on 22 Oct 2013

HAL is a multi-disciplinary open access archive for the deposit and dissemination of scientific research documents, whether they are published or not. The documents may come from teaching and research institutions in France or abroad, or from public or private research centers.
L'archive ouverte pluridisciplinaire HAL, est destinée au dépôt et à la diffusion de documents scientifiques de niveau recherche, publiés ou non, émanant des établissements d'enseignement et de recherche français ou étrangers, des laboratoires publics ou privés. 


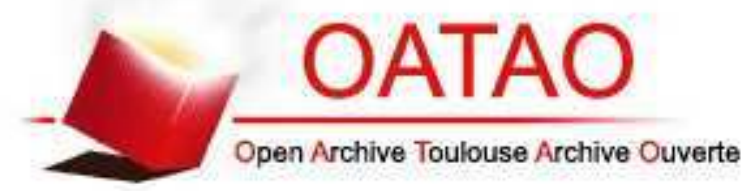

\section{Open Archive TOULOUSE Archive Ouverte (OATAO)}

OATAO is an open access repository that collects the work of Toulouse researchers and makes it freely available over the web where possible.

This is an author-deposited version published in : http://oatao.univ-toulouse.fr/ Eprints ID : 9767

To link to this article : DOI:10.1016/j.corsci.2013.04.042

URL : http://dx.doi.org/10.1016/j.corsci.2013.04.042

To cite this version : Trompette, Jean-Luc and Massot, Laurent and Vergnes, Hugues. Influence of the oxyanion nature of the electrolyte on the corrosion/passivation behaviour of nickel. (2013) Corrosion Science, vol. 74 . pp. 187-193. ISSN 0010-938X

Any correspondance concerning this service should be sent to the repository administrator: staff-oatao@ listes-diff.inp-toulouse.fr 


\title{
Influence of the oxyanion nature of the electrolyte on the corrosion/ passivation behaviour of nickel
}

\author{
J.L. Trompette*, L. Massot, H. Vergnes \\ Laboratoire de Génie Chimique (LGC), UMR 5503, 4 allée Emile Monso, 31432 Toulouse Cedex 4, France
}

Keywords:

A. Nickel

B. Polarization

B. SIMS

B. XPS

C. Anodic films

C. Pitting corrosion

\begin{abstract}
A B S T R A C T
The electrochemical behaviour of nickel in the presence of various electrolyte solutions at $0.1 \mathrm{~mol} / \mathrm{L}$ concentration exhibits a distinction according to the oxyanion nature of the investigated anions. Passivity is achieved with oxyanions whereas it fails with anions not containing oxygen. SIMS and XPS measurements performed from isotopic and non isotopic $\mathrm{KNO}_{3}$ electrolytes indicate that the oxygen and nitrogen atoms from nitrate oxyanions are incorporated into the passive film during anodic polarization and with evidence of a direct bonding between nitrogen and nickel surface.
\end{abstract}

\section{Introduction}

Some previous studies were shown to rationalize the influence of anion specificity on the corrosion/passivation behaviour of some valve metals such as aluminium, titanium and tantalum [1-3]. These metals are characterized by the presence of a natural passive oxide film with a thickness of a few nanometers (2-5 nm typically) which is formed spontaneously when they are exposed to oxidizing media (air, water). The resistance of valve metals against corrosion originates from the propensity of this passive film to regenerate sufficiently quickly and cohesively after an eventual breakdown.

The investigated anions were conveniently distinguished according to the sign of the viscosity $B$ coefficient value between the kosmotropes with $B>0$ and the chaotropes with $B<0$. Once the hydrated anions are adsorbed on the surface of the passive film, they may be involved in a thinning process of the passive film through the formation of soluble salts or complexes with surface metallic cations. Although this thinning process is challenged with the concomitant pronounced repassivation (regeneration) of valve metals, the chaotrope anions that are able to dehydrate easily can penetrate into the passive film and thus initiate localized corrosion. At the contrary, passivity was found to occur with the kosmotrope anions that tend to preserve their surrounding hydration shell (the energetic dehydration contribution is too unfavourable);

\footnotetext{
* Corresponding author. Tel.: +33053432 36 34; fax: +33053432 3697 E-mail address: jeanluc.trompette@ensiacet.fr (J.L. Trompette).
}

so reflecting that in such conditions the thinning process could not overcompensate film regeneration of the valve metals [2].

It seems therefore interesting from a fundamental point of view to investigate whether the previous trends may be applied to other types of metals with different properties.

Owing to its recognized resistance against corrosion, which is a domain of high technological and economical importance, nickel has been used pure or as an alloying element. It has been the subject of a considerable amount of studies concerning its electrochemical behaviour in many electrolytes and at varying $\mathrm{pH}$ [430], together with the mechanisms of formation of passive films, their nature, structure and properties [31-47]. The thin air-formed passive film on nickel surface is highly defective and may be removed easily. It is not so cohesive and prone to regeneration as that for the valve metals. However according to various anodization treatments and different experimental conditions, the resulting anodic oxide films were found to exhibit excellent resistance to breakdown. Based on these studies, a duplex structure of the passive film is generally proposed with an inner layer of crystalline $\mathrm{NiO}$ with a thickness up to $1.2 \mathrm{~nm}$, and an outer layer of amorphous $\mathrm{Ni}(\mathrm{OH})_{2}$ with a thickness up to $0.6 \mathrm{~nm}$ [48], although it has been reported that much thicker films may be obtained in specific conditions [34,40].

According to the Pourbaix diagram of nickel [49], this metal is naturally passive when the solution $\mathrm{pH}$ is greater than about 8 and its immunity is preserved when the applied electrical potential is lower than its equilibrium potential. When the solution $\mathrm{pH}$ is acid, neutral or weakly basic, nickel (Ni) is known to present often an active-passive transition when increasing the electrical poten- 
tial in many electrolyte solutions. After an activation region where the electrical current increases, the current exhibits a maximum (say a peak) before it decreases abruptly to remain nearly constant during a variable range of electrical potential, and it increases finally due to oxygen evolution and/or transpassive metal dissolution $[8,13]$.

In this study, the electrochemical behaviour of nickel in the presence of various electrolytes has been investigated. The results were complemented by SIMS and XPS measurements from non isotopic and isotopic $\mathrm{KNO}_{3}$ electrolytes to appreciate the eventual incorporation of oxygen and nitrogen atoms into the passive film.

\section{Material and methods}

All the salts used: sodium fluoride (NaF), sodium chloride $(\mathrm{NaCl})$, sodium bromide $(\mathrm{NaBr})$, potassium iodide $(\mathrm{KI})$, sodium perchlorate $\left(\mathrm{NaClO}_{4}\right)$, potassium nitrate $\left(\mathrm{KNO}_{3}\right)$, sodium thiocyanate $(\mathrm{NaSCN})$, sodium formate $\left(\mathrm{NaHCO}_{2}\right)$, sodium acetate $\left(\mathrm{NaCH}_{3} \mathrm{CO}_{2}\right)$, sodium hydrogenophosphate $\left(\mathrm{NaH}_{2} \mathrm{PO}_{4}\right)$, sodium sulfate $\left(\mathrm{Na}_{2} \mathrm{SO}_{4}\right)$, were analytical grade products manufactured by Prolabo (France) or Sigma-Aldrich (France). Isotopic potassium nitrate $\left(\mathrm{K}^{15} \mathrm{~N}^{18} \mathrm{O}_{3}\right.$, $15 \mathrm{~N}-98 \%, 180-95 \%$ ) was purchased from Santa Cruz Biotechnology (USA).

Deionized water was taken as a solvent to prepare the electrolyte solutions at $0.1 \mathrm{~mol} / \mathrm{L}$ concentration. The $\mathrm{pH}$ of the electrolyte solutions was measured with an electronic pH-meter (Hanna Instrument). When the $\mathrm{pH}$ of the original electrolyte solution was too basic, say around $\mathrm{pH} 8$, droplets of the following acids were added to decrease the $\mathrm{pH}$ value of the corresponding electrolyte solution: fluoric acid (HF) solution at $40 \mathrm{wt} . \%$ (Prolabo) in the case of $\mathrm{NaF}$ electrolyte solution, formic acid $\left(\mathrm{HCO}_{2} \mathrm{H}\right)$ solution at 98.5 wt.\% (Prolabo) in the case of $\mathrm{NaHCO}_{2}$ electrolyte solution, and acetic acid $\left(\mathrm{CH}_{3} \mathrm{CO}_{2} \mathrm{H}\right)$ solution at $99 \mathrm{wt}$.\% (Prolabo) in the case of $\mathrm{NaCH}_{3} \mathrm{CO}_{2}$ electrolyte solution.

Small nickel plates were cut from a commercial Ni foil (99\%, Goodfellow, UK) with a thickness of $0.5 \mathrm{~mm}$ to obtain rectangular shape $(1.5 \mathrm{~cm} \times 0.8 \mathrm{~cm})$. Before any experiment, the plates were washed in acetone and rinsed with deionized water. Then, the plates were electropolished twice during $2 \mathrm{~min}$ in a $57 \%$ sulfuric acid solution at a $0.5 \mathrm{~A} / \mathrm{cm}^{2}$ current density. They were finally rinsed with deionized water and dried in air.

The electrochemical experiments were performed with a potentioscan (Radiometer Analytical S.A. Copenhagen, Tacussel DEA 332, potential range $0-8 \mathrm{~V}$ ) coupled with a digital converter (Radiometer Analytical, IMT 102) and controlled by a PC running the electrochemical software (Radiometer Analytical, VoltaMaster 2). The electrochemical set up was constituted with a nickel plate as the working electrode and a large flat platinum plate as the auxiliary electrode. The plates were immersed at $1 \mathrm{~cm}$ depth in $50 \mathrm{~mL}$ of the studied solution. A mercurous sulfate electrode (MSE), $\mathrm{Hg} /$ $\mathrm{HgSO}_{4} / \mathrm{K}_{2} \mathrm{SO}_{4}$ saturated solution, served as a reference electrode. All the reported potential values refer to this reference electrode.

Linear voltammograms were performed in the range -1 to $+1 \mathrm{~V} / \mathrm{MSE}$ with a $5 \mathrm{mV} / \mathrm{s}$ sweep rate under agitation at $200 \mathrm{rpm}$ (magnetic stirrer) of the studied solution. The same device was used for chronoamperometric experiments where the current intensity was recorded as a function of time at an imposed electrical potential.

The voltammograms were performed at ambient temperature and repeated once to confirm the reliability of the electrochemical results.

For the SIMS and XPS measurements, linear voltammograms were performed on nickel plates from -1 to $0.7 \mathrm{~V} / \mathrm{MSE}$ with a $5 \mathrm{mV} / \mathrm{s}$ sweep rate under agitation at $200 \mathrm{rpm}$ (magnetic stirrer) in the studied electrolyte solution. The treated plates were thor- oughly rinsed with deionised water and dried in air before they were analysed.

A Cameca IMS 4F6 apparatus was used for SIMS analysis. Sputtering was performed with a $2 \mathrm{keV}$ cesium ion beam. The incident angle of the ion beam was $45^{\circ}$ with respect to the sample surface. A square area with a $150 \mu \mathrm{m}$ edge length was attacked by the beam and the $20 \%$ central area of the crater was analyzed. For SIMS analysis, the masses used were $16\left({ }^{16} \mathrm{O}\right), 18\left({ }^{18} \mathrm{O}\right), 72\left({ }^{58} \mathrm{Ni}^{14} \mathrm{~N}\right), 73$ $\left({ }^{58} \mathrm{Ni}^{15} \mathrm{~N}\right)$. The natural isotopic abundancies are: $0.20 \%$ and $0.36 \%$ for ${ }^{18} \mathrm{O}$ and ${ }^{15} \mathrm{~N}$ respectively [50].

A K-alpha apparatus (Thermo Scientific) was used for XPS analysis. The excitation source is a monochromatic ray $\mathrm{Al} \mathrm{Ka}$ $(1486.6 \mathrm{eV})$. Binding energies are calibrated with respect to the $\mathrm{C}-\mathrm{C}$ bond of $\mathrm{C} 1 \mathrm{~s}$ at $284.4 \mathrm{eV}$. Etching was applied during $5 \mathrm{~s}$ with an argon ion beam at $1 \mathrm{keV}$. XPS measurements were first performed with untreated nickel sample that served as a blank of reference for further assignment of the peaks for the treated samples. The peaks corresponding to the binding energies of $\mathrm{Ni} 2 \mathrm{p}_{3 / 2}$ at $852.46 \mathrm{eV}$ (76.48\% at.), $856.40 \mathrm{eV}$ (3.43\% at.), $858.60 \mathrm{eV}(11.94 \%$ at.) were detected, together with $\mathrm{O} 1 \mathrm{~s}$ at $531.95 \mathrm{eV}(8.15 \%$ at.).

After the chronoamperometric experiments, a 3CCD digital video camera, Panasonic NV-GS 120 (Crystal Engine), was used to take photographs of the plates.

\section{Results and discussion}

\subsection{Comparative linear voltammograms}

The anodic polarization of $\mathrm{Ni}$ in the presence of the studied electrolytes is reported in Figs. 1-3. For $\mathrm{NaHCO}_{2}, \mathrm{NaCH}_{3} \mathrm{CO}_{2}$ and $\mathrm{NaF}$ electrolytes, the $\mathrm{pH}$ of the prepared solution is too high so that $\mathrm{Ni}$ remains passive: the current density is very low and the activepassive transition (say the peak) is not observed. Indeed when
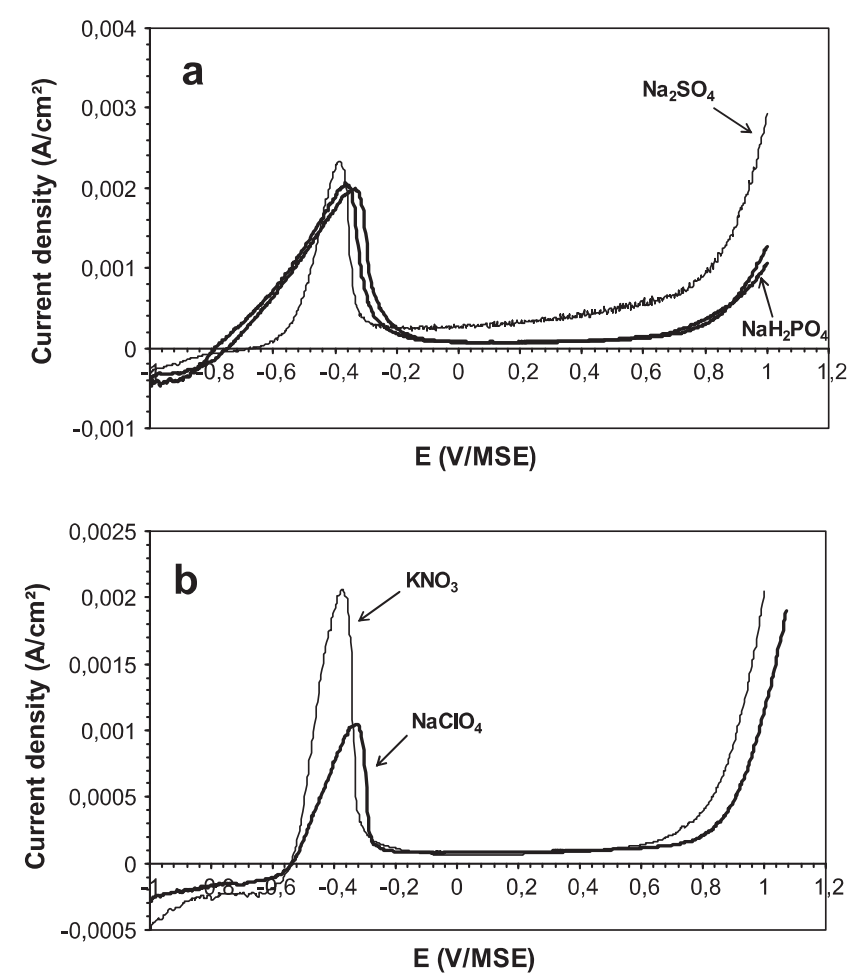

Fig. 1. Linear voltammograms with (a) $\mathrm{Na}_{2} \mathrm{SO}_{4}$ (thin curve), $\mathrm{NaH}_{2} \mathrm{PO}_{4}$ (thick curves) electrolytes at $0.1 \mathrm{~mol} / \mathrm{L}$ concentration and with (b) $\mathrm{KNO}_{3}$ (thin curve), $\mathrm{NaClO}_{4}$ (thick curve) electrolytes at $0.1 \mathrm{~mol} / \mathrm{L}$ concentration. 

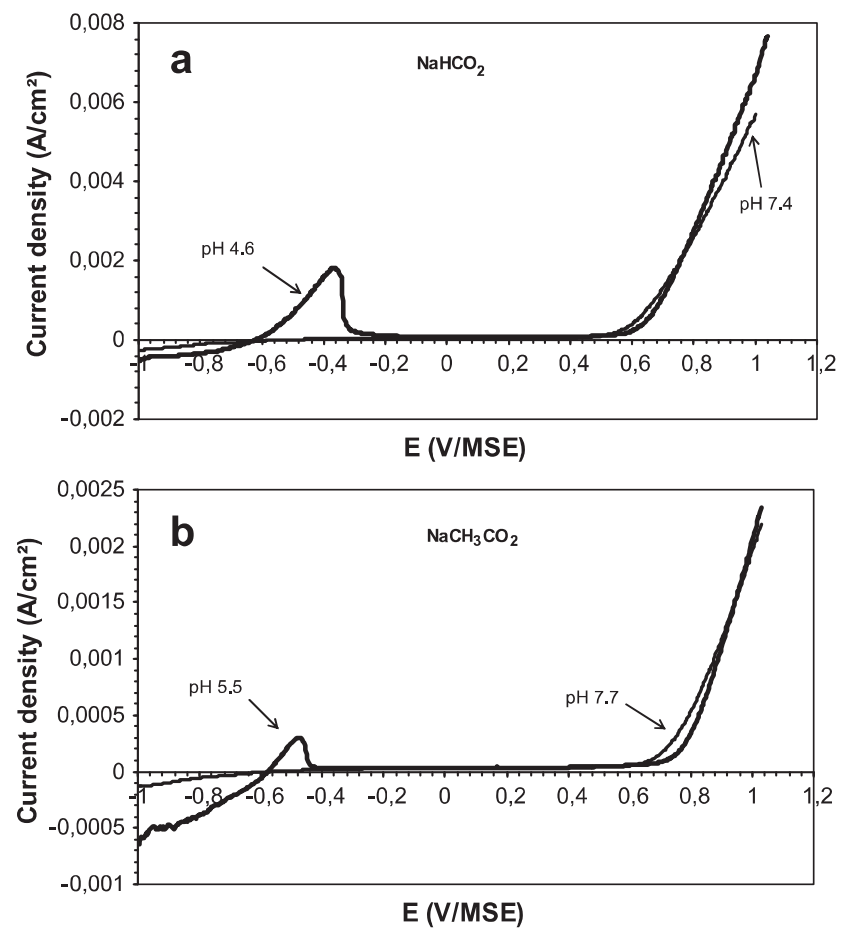

Fig. 2. Linear voltammograms with (a) $\mathrm{NaHCO}_{2}$ and (b) $\mathrm{NaCH}_{3} \mathrm{CO}_{2}$ electrolytes at $0.1 \mathrm{~mol} / \mathrm{L}$ concentration at original $\mathrm{pH}$ value (thick curves) and modified $\mathrm{pH}$ value (thicker curves).
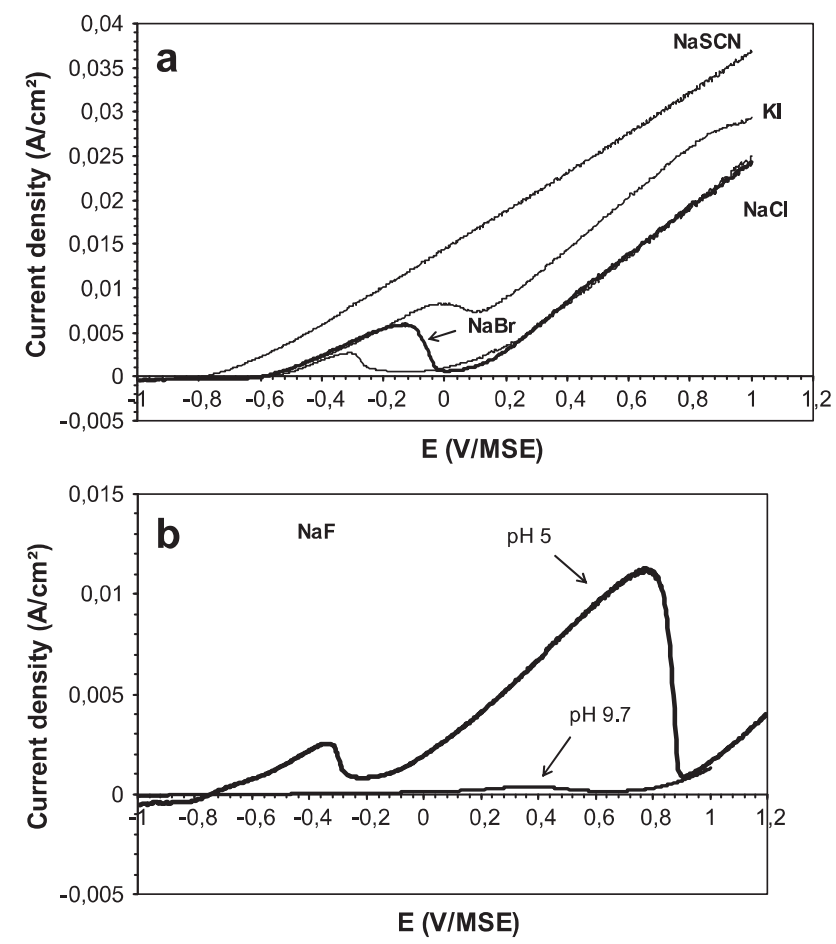

Fig. 3. Linear voltammograms with (a) $\mathrm{NaCl}, \mathrm{NaBr}$ (thick curve), $\mathrm{KI}, \mathrm{NaSCN}$ electrolytes at $0.1 \mathrm{~mol} / \mathrm{L}$ concentration and with (b) $\mathrm{NaF}$ electrolyte at $0.1 \mathrm{~mol} / \mathrm{L}$ concentration at original $\mathrm{pH}$ value (thick curve) and modified $\mathrm{pH}$ value (thicker curve).

metallic nickel is immersed in sufficiently aqueous alkaline solution the spontaneous formation of a nickel (II) hydroxide passive layer, $\mathrm{Ni}(\mathrm{OH})_{2}$, may result [51]. To prevent such cases, few droplets of the corresponding acid were added to decrease the solution $\mathrm{pH}$ value (see Section 2). The polarization curves at original and modified $\mathrm{pH}$ values have been superimposed in Fig. 2 for $\mathrm{NaHCO}_{2}$ and $\mathrm{NaCH}_{3} \mathrm{CO}_{2}$, and in Fig. 3 for NaF.

For $\mathrm{Na}_{2} \mathrm{SO}_{4}$ with original pH 6.2 (thin curve), and $\mathrm{NaH}_{2} \mathrm{PO}_{4}$ with original pH 4.6 (thick curves), see case a in Fig. 1, the behaviour is in accordance with the expected trends. As an indication, the two runs performed with $\mathrm{NaH}_{2} \mathrm{PO}_{4}$ electrolyte were plotted to appreciate the reproducibility of the results. Oxygen evolution is found to occur around $0.7 \mathrm{~V} / \mathrm{MSE}$. After the top of the peak, the steep decrease of the current density followed by the wide constant region indicates the establishment of passivity owing to the formation of the oxide film on the metal surface according to the oxidation reaction [4]:

$\mathrm{Ni}+\mathrm{H}_{2} \mathrm{O} \rightarrow \mathrm{NiO}+2 \mathrm{H}^{+}+2 e^{-}$

For $\mathrm{KNO}_{3}$ with original pH 5.5 (thin curve), and $\mathrm{NaClO}_{4}$ with original pH 5.3 (thick curve), see case b in Fig. 1, the results are similar.

For $\mathrm{NaHCO}_{2}$, see case a in Fig. 2, and $\mathrm{NaCH}_{3} \mathrm{CO}_{2}$, see case b in Fig. 2, the behaviour is of the same type as previously when the $\mathrm{pH}$ is decreased to allow the active-passive transition to occur, say from original pH 7.4 (thick curve) to 4.6 (thicker curve) for instance with $\mathrm{NaHCO}_{2}$, and from original pH 7.7 (thick curve) to 5.5 (thicker curve) for instance with $\mathrm{NaCH}_{3} \mathrm{CO}_{2}$.

For these first six electrolytes where passivity is observed, the active-passive transition is located approximately around $-0.4 \mathrm{~V} /$ MSE with a steep decrease of the current density after the top of the peak and the extent of the passive region is pronounced. The nickel plates remain bright and no sign of attack is observed.

For $\mathrm{NaCl}$ with original $\mathrm{pH} 5.4, \mathrm{NaBr}$ with original $\mathrm{pH} 5.5$ (thick curve), and $\mathrm{KI}$ with original pH 6.1, see case a in Fig. 3, the decrease of the anodic current after the top of the peak is not as sharp as that classically associated with the occurrence of passivity and the minimum current is still high just before the current density increases definitively, well before oxygen evolution takes place.

For NaSCN with original pH 5.6, see case a in Fig. 3, there is no active-passive transition. The current density increases continuously within the investigated potential range. A black deposit of nickel sulfide ( $\mathrm{NiS}$ or $\mathrm{Ni}_{3} \mathrm{~S}_{2}$ ) forms from the beginning on the surface [52]. The formation of sulfide has been assumed to result from the reaction of the metal with elemental sulfur originating from the decomposition of some thiocyanate anions at the nickel surface according to: $\mathrm{SCN}^{-}=\mathrm{S}+\mathrm{CN}^{-}$[53].

For these electrolytes (case a in Fig. 3), the observed linear increase of the current density is characteristic of a pure resistive system (ohmic regime). The resistance of the system was indeed found to correspond to that of the electrolyte solution. During this increase, intensive hydrogen bubbling occurs at the platinum plate and the $\mathrm{pH}$ becomes increasingly basic. As expected the plates have been pitted.

For NaF, see case b in Fig. 3, there is a significant influence of the solution $\mathrm{pH}$. As expected, Ni remains passive in the as-prepared basic solution with original pH 9.7 (thick curve) whereas two maxima are observed when the $\mathrm{pH}$ is lowered to 5 (thicker curve). After the activation region, the current density decreases similarly as with the previous halides (without a wide constant region) before it increases up to the second maximum characterized by a steep decrease, and followed by a final increase due to oxygen evolution. The presence of this second maximum has been already studied; it was ascribed to the formation of a passivating $\mathrm{NiF}_{2}$ layer $[19,20]$.

As information, during the cathodic polarization of nickel in the presence of the electrolyte solutions a current density plateau is observed that corresponds to the reduction of dissolved oxygen. 


\subsection{Comparison of aggressive behaviours}

Based on the previous results, the aggressiveness of $\mathrm{NaSCN}$, $\mathrm{NaBr}, \mathrm{NaF}$ at $\mathrm{pH} 5$, and $\mathrm{KNO}_{3}$ solutions has been inspected through chronoamperometric experiments. Whereas passivity was found to occur with the first six studied electrolytes, say the current density remained at a low level during a long range of potential before oxygen evolution at around $0.7 \mathrm{~V} / \mathrm{MSE}$, signs of attack were apparent with the other electrolytes where the current density increased continuously with the potential. It is thus pertinent to choose a potential value within this potential range. Chronoamperometric experiments were performed at $0.4 \mathrm{~V} / \mathrm{MSE}$ electrical potential during $20 \mathrm{~min}$. The corresponding curves are shown in Fig. 4. The involved valence $z$ was determined according to the Faraday's law:

$z=\frac{Q M_{\mathrm{Ni}}}{F \Delta m}$

where $Q$ is the amount of charge passed during electrolysis duration ( $Q=\int i \mathrm{~d} t$ corresponds to the chronoamperometric curve area; it is calculated by the VoltaMaster 2 software), $M_{\mathrm{Ni}}$ is the atomic weight of nickel, $F$ is the Faraday constant, $\Delta m$ is the weight loss of a nickel plate.

The results are: $z=2.21,2.07$ and 2.04 for $\mathrm{NaSCN}, \mathrm{NaBr}$ and $\mathrm{NaF}$ at pH 5 respectively. For $\mathrm{KNO}_{3}$ no $z$ value can be calculated since the weight of the Ni plate was unchanged. The obtained $z$ values indicate a corrosion process releasing nickel II species in accordance with the oxidation reaction [7]:

$\mathrm{Ni} \rightarrow \mathrm{Ni}^{2+}+2 e^{-}$

Photographs of the corresponding nickel plates are shown in Fig. 5. In the case of NaSCN, the formation of the nickel sulfide black deposit does not prevent pitting to occur [52]. The presence of adsorbed sulfur was known to enhance metal dissolution by weakening the bonds between the metal atoms and to exert a poisoning effect by inhibiting the growth of an oxide passive film [54,55]. Pits are present with $\mathrm{NaBr}$ (see Fig. 5) whereas the plate is uniform with $\mathrm{NaF}$ at $\mathrm{pH} 5$ although its aspect is dull, not as bright as it is observed with $\mathrm{KNO}_{3}$ where no attack has occurred, as expected.

Among the halides, the attack of nickel by fluorides has been already reported to be different from the others (say chloride, bromide, iodide) [17]. Whereas a general corrosion process of the oxide film, through a uniform dissolution, was found to occur with fluoride, a localized attack of the passive oxide film, corresponding to a pitting corrosion process, was obtained with the other halides [27]. The invoked argument to interpret this discrepancy was ascribed to the decreasing magnitude of the stability constants, from fluoride to iodide, of the resulting soluble complexes with the surface metallic cations during the thinning process of the passive

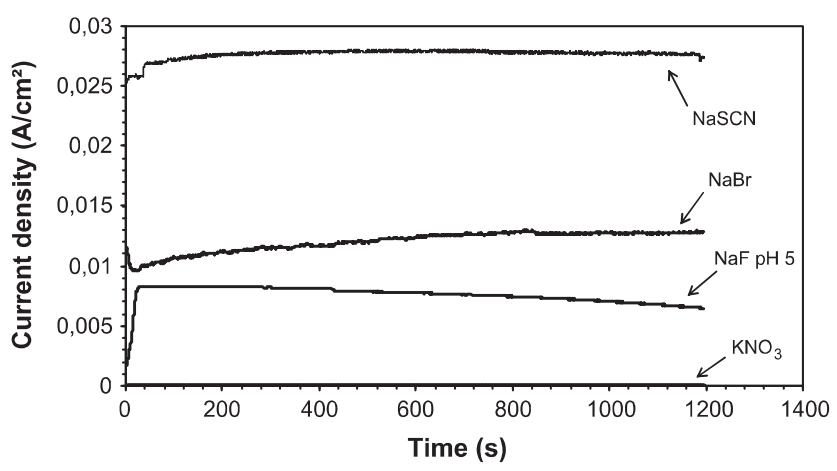

Fig. 4. Chronoamperometric curves at $0.4 \mathrm{~V} / \mathrm{MSE}$ for $\mathrm{NaSCN}, \mathrm{NaBr}, \mathrm{NaF}$ at $\mathrm{pH} 5$ and $\mathrm{KNO}_{3}$ electrolytes at $0.1 \mathrm{~mol} / \mathrm{L}$ concentration.

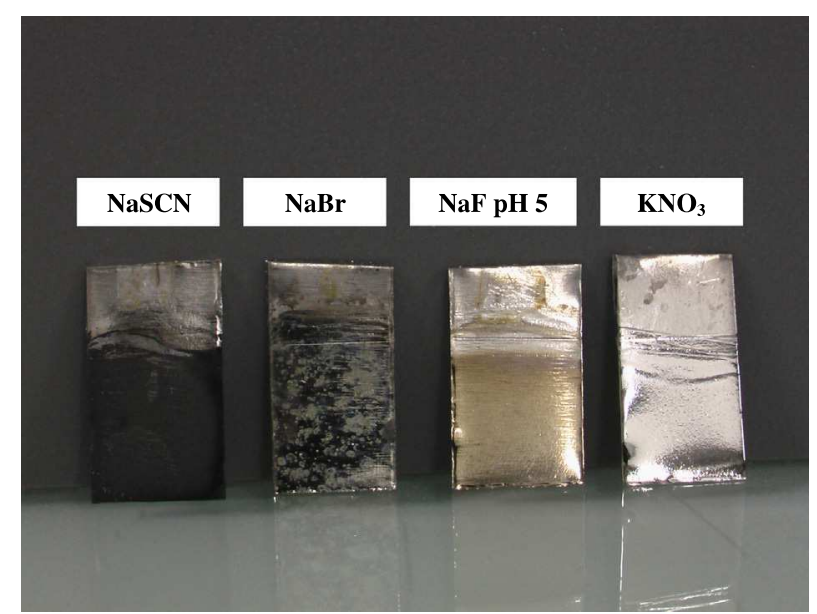

Fig. 5. Photograph of nickel plates after the chronoamperometric experiments.

layer [56]. Interestingly, the concept of the categorization of anions offers the opportunity to interpret, in a complementary way, this distinction in the corrosion mechanism between the halides since fluoride is a kosmotrope anion whereas the others are chaotropes [1]. Once the halides are adsorbed on the surface of the passive layer, they participate to a thinning process of this film through the formation of soluble complexes. However, as the chaotrope halides such as chloride, bromide and iodide, are prone to loose their hydration shell, they may be also able to penetrate into the passive layer so that the attack is localized and therefore pitting is observed. As the fluoride anions tend to preserve their hydration shell, pitting is precluded [2]. The thinning process may thus be assumed to be widespread over the whole surface of the passive layer and the attack is then more uniform, as it is effectively observed.

Despite the breakdown of passive film of valve metals was found in the presence of the chaotrope nitrate $\left(\mathrm{NO}_{3}^{-}\right)$and perchlorate $\left(\mathrm{ClO}_{4}^{-}\right)$anions [1,2], passivity of nickel is observed with these two oxyanions whereas passivity breakdown occurs with the other chaotrope anions not containing oxygen $\left(\mathrm{Cl}^{-}, \mathrm{Br}^{-}, \mathrm{I}^{-}, \mathrm{SCN}^{-}\right)$. With the tested kosmotrope anions $\left(\mathrm{SO}_{4}^{2-}, \mathrm{H}_{2} \mathrm{PO}_{4}^{-}, \mathrm{F}, \mathrm{HCO}_{2}^{-}, \mathrm{CH}_{3} \mathrm{CO}_{2}^{-}\right)$, which are expected to be less aggressive, passivity due to an oxide film is preserved except in the case of fluoride which is among them the sole anion not containing oxygen. These observations related to the oxyanion nature of the studied electrolytes are somewhat unexpected and should deserve deeper investigations. If it is not a coincidence, this opens the question whether the oxyanions could contribute to passivate the nickel surface by their oxygen atoms, as it has been hypothesized in few studies in the past [15].

\subsection{SIMS and XPS analysis}

SIMS measurements of passive films elaborated on $\mathrm{Ni}$ from anodization treatments in the presence of $\mathrm{H}_{2} \mathrm{O}$ solvent molecules enriched in isotopic oxygen ${ }^{18} \mathrm{O}$ were useful to show the sequence of breakdown and repair events within the oxide film $[42,48]$.

SIMS measurements were used here to determine whether the constitutive oxygen atoms from a representative oxyanion are detected into the passive film. For that purpose, linear voltammograms were performed on nickel plates from -1 to $0.7 \mathrm{~V} / \mathrm{MSE}$, say up to the end of the passive region before oxygen evolution (see case b in Fig. 1), with an aqueous solution of isotopic $\mathrm{K}^{15} \mathrm{~N}^{18} \mathrm{O}_{3}$ electrolyte and with an aqueous solution of non isotopic $\mathrm{KNO}_{3}$ electrolyte, both at $0.1 \mathrm{~mol} / \mathrm{L}$ concentration. The treated plates were analysed comparatively. The used isotopic electrolyte allowed investigating if nitrogen atoms were also present into 
the passive film. However the signals of ${ }^{14} \mathrm{~N}$ and ${ }^{15} \mathrm{~N}$ were too unreliable, they decreased steeply from the beginning and remained at a very low intensity level. The response of the fragments $\mathrm{Ni}^{14} \mathrm{~N}$ and $\mathrm{Ni}^{15} \mathrm{~N}$ were then recorded. The comparative results are reported in Fig. 6.

The natural abundancy of the ${ }^{16} \mathrm{O}$ and ${ }^{18} \mathrm{O}$ isotopes is $99.76 \%$ and $0.20 \%$ respectively [51]; the isotopic ratio $\left({ }^{16} \mathrm{O} /{ }^{18} \mathrm{O}\right)$ corresponds to 498.8, say about 500. For non isotopic $\mathrm{KNO}_{3}$ electrolyte, see case a in Fig. 6, the ratio of the intensity at the top of the curves in the prime instants for the response of ${ }^{16} \mathrm{O}$ and ${ }^{18} \mathrm{O}$ corresponds nearly to 500 , say the expected isotopic ratio, and this ratio remains constant during analysis. This can be estimated by the separation distance between the two curves. For isotopic $\mathrm{K}^{15} \mathrm{~N}^{18} \mathrm{O}_{3}$ electrolyte, see case $b$ in Fig. 6 , the response of ${ }^{16} \mathrm{O}$ is practically unchanged whereas that of ${ }^{18} \mathrm{O}$ is increased. At the top of the curves the ratio is about 105 , say the separation distance is shorter than in case $a$, and the curves diverge from one another with time analysis, so reflecting that the separation distance tends to equal that in case a. This indicates that the proportion of ${ }^{18} \mathrm{O}$ is about 5 times greater in the film with isotopic $\mathrm{KNO}_{3}$ than it is in the film with natural $\mathrm{KNO}_{3}$. This proves the presence of oxygen atoms from the $\mathrm{NO}_{3}^{-}$ oxyanion into the passive film. Moreover, the level of the response of the fragments $\mathrm{Ni}^{14} \mathrm{~N}$ and $\mathrm{Ni}^{15} \mathrm{~N}$ is observed to be inversed when comparing cases $a$ and $b$ in Fig. 6 . This result suggests that nitrogen atoms originating from $\mathrm{KNO}_{3}$ electrolyte are also present into the passive film.

XPS measurements were performed with a new nickel plate that was treated in the same conditions as previously with $\mathrm{KNO}_{3}$ electrolyte, say linear voltammogram from -1 to $0.7 \mathrm{~V} / \mathrm{MSE}$. It was compared with the XPS analysis of a nickel plate treated with $\mathrm{NaClO}_{4}$ electrolyte in the same conditions and where no nitrogen is expected to be detected. The results are reported in Fig. 7. The analysis before (thin curves) and after argon-ion etching (thick curves) have been superimposed.
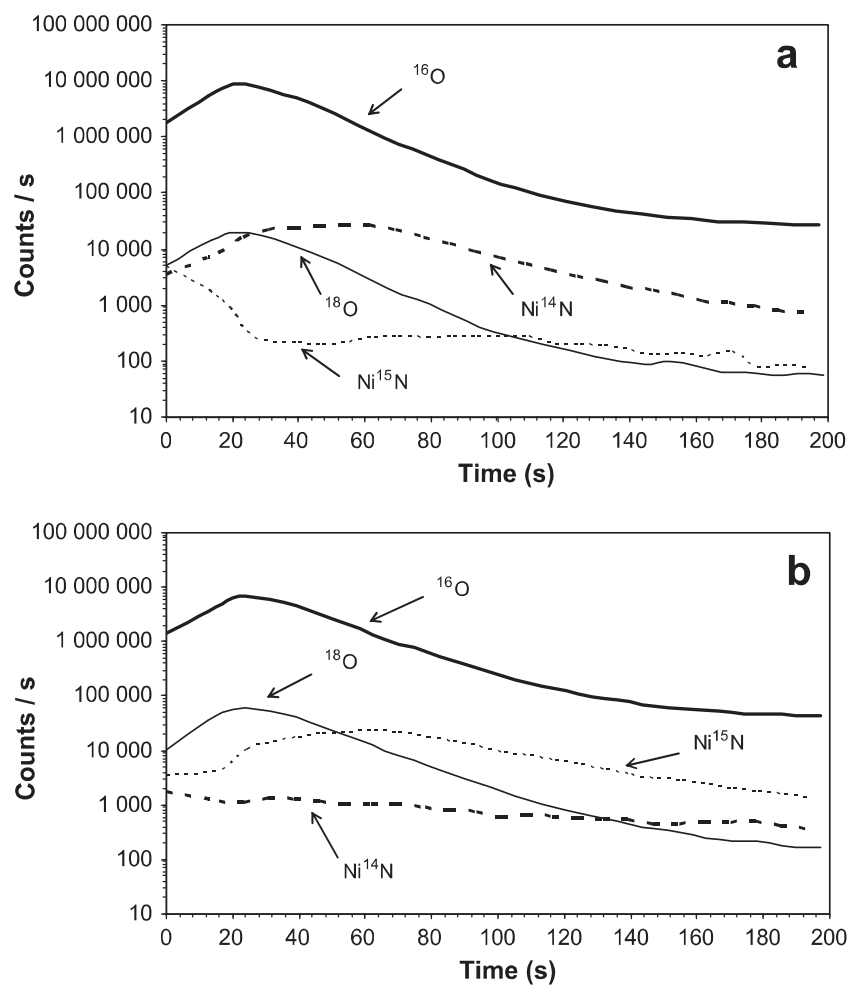

Fig. 6. SIMS measurements for a nickel plate after passivation (a) in $\mathrm{KNO}_{3}$ electrolyte and (b) in $\mathrm{K}^{15} \mathrm{~N}^{18} \mathrm{O}_{3}$ isotopic electrolyte.
Concerning the XPS analysis of $01 \mathrm{~s}$ in the passive film formed from $\mathrm{KNO}_{3}$ electrolyte, the presence of two peaks has been already mentioned $[13,48]$. They correspond to the position of oxygen atom in $\mathrm{NiO}(529.6 \mathrm{eV})$ and $\mathrm{Ni}(\mathrm{OH})_{2}(531.3 \mathrm{eV})[13,35]$. As expected the peak corresponding to the inner layer $\mathrm{NiO}$ of the duplex structure is enhanced after etching (the outer layer being more altered). The analysis of $\mathrm{N} 1 \mathrm{~s}$ from $\mathrm{KNO}_{3}$ electrolyte shows the presence of two peaks corresponding to binding energies at $397.6 \mathrm{eV}$ and $400 \mathrm{eV}$. The peak at $397.6 \mathrm{eV}$ is accentuated after etching whereas that at $400 \mathrm{eV}$ is significantly decreased and appears as a slight shoulder that can hardly be considered as a peak without great uncertainties. This reflects that the peak at $397.6 \mathrm{eV}$ corresponds to nitrogen that is located sufficiently deep inside the passive film. The atomic percentage of $\mathrm{N} 1 \mathrm{~s}$ in the film is found to be $2.0 \pm 0.5 \%$. When the comparison is made with the analysis of $\mathrm{N} 1 \mathrm{~s}$ from the passive film formed from $\mathrm{NaClO}_{4}$, see Fig. 7, the peak at $397.6 \mathrm{eV}$ is absent so confirming that it corresponds indubitably to nitrogen originating from $\mathrm{NO}_{3}^{-}$oxyanion. That at $400 \mathrm{eV}$ is weakly present, so confirming it cannot be assigned to any $\mathrm{KNO}_{3}$ origin, but it disappears after etching. It may be suggested that it corresponds to some inherent impurities that are easily removed by etching, owing to poor interactions with the metal surface.

Knowing that for $\mathrm{N} 1 \mathrm{~s}$ in condensed $\mathrm{KNO}_{3}$ a binding energy of $407.2 \mathrm{eV}$ is expected [57], such a large shift of the binding energy to $397.6 \mathrm{eV}$ suggests a direct bonding between nitrogen and the metal. According to the table of XPS $\mathrm{N} 1 \mathrm{~s}$ binding energies for nitrogen compounds on transition metal surfaces given in reference [58], the peak at $397.6 \mathrm{eV}$ can be effectively assigned to $\mathrm{Ni}-\mathrm{N}$ bonding $[59,60]$. As an indication, the binding energy of $\mathrm{Fe}-\mathrm{N}$ was reported to be $397.3 \mathrm{eV}$ [61]; that for $\mathrm{Zr}-\mathrm{N}$ and $\mathrm{Ti}-\mathrm{N}$ were $397.7 \mathrm{eV}$ and $397.0 \mathrm{eV}$, respectively [62].

The results inferred from SIMS and XPS measurements indicate that the oxygen and nitrogen atoms from $\mathrm{NO}_{3}^{-}$oxyanions are incorporated into the passive film during anodic polarization. Moreover passivity was observed to occur with all the investigated oxyanions. These results support the assumption that the oxygen atoms of the oxyanions should contribute, to some extent, to participate to NiO film formation and/or to consolidate this passive film. The presence of the first maximum (say the peak) on the polarization curves reflects the concomitant occurrence of two antagonist effects during the increase of the electrical potential: the activation phase where metal dissolution occurs and the passivating phase where the oxide film builds on the surface. In conditions where the oxide film can develop over the whole surface without being damaged and even reinforced, passivity is then achieved: the current density decreases abruptly and remains at a low level. If the incipient oxide film is damaged by aggressive anions, the regeneration (repassivation) of this film on nickel is not as pronounced as that for valve metals and thus the current density increases again after the first maximum, so indicating that the substrate is attacked (through a general or pitting corrosion process). This is what was observed in the presence of anions not containing oxygen.

These results may provide useful information concerning the mechanism of action of inhibiting anions, which very often are oxyanions, when metal substrates are in the presence of aggressive species. It has been assumed that inhibitors can compete with aggressive anions on adsorption sites at the passive layer surface and/or they could be incorporated into the passive layer by plugging pores and flaws so allowing an enhanced stability against the attack of aggressive anions [15,22,63,64].

The existence of $\mathrm{Ni}-\mathrm{N}$ bonding suggests that a decomposition of $\mathrm{NO}_{3}^{-}$oxyanions at the nickel surface during anodic polarization may be envisaged (at least partially). It has to be noted that water itself may be seen as undergoing a decomposition process. Indeed, reaction (1) signifies there is a direct electrochemical reaction be- 

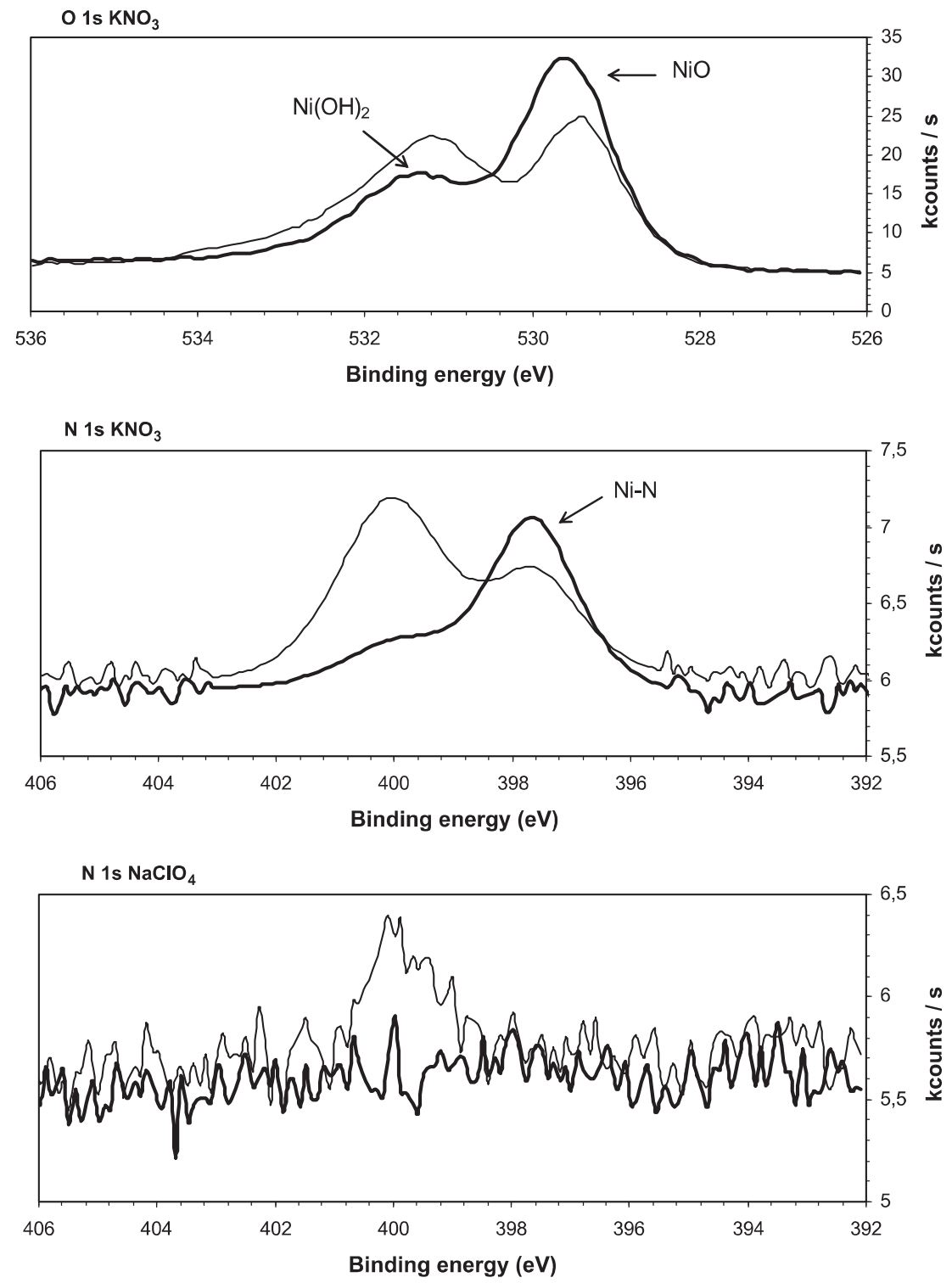

Fig. 7. $\mathrm{O} 1 \mathrm{~s}$ and $\mathrm{N} 1 \mathrm{~s}$ photoelectron spectra for a nickel plate after passivation in $\mathrm{KNO}_{3}$ electrolyte before (thin curves) and after argon-ion etching (thick curves); and $\mathrm{N} 1 \mathrm{~s}$ photoelectron spectrum for a nickel plate after passivation in $\mathrm{NaClO}_{4}$ electrolyte before (thin curve) and after argon-ion etching (thick curve).

tween Ni surface and water, and thus implicitly that Ni is able to get the oxygen atom off the water molecule to allow formation of the oxide film. This means that two hydrogen bonds should have to be broken. Knowing that the bond energy of $\mathrm{O}-\mathrm{H}$ is $467 \mathrm{~kJ} / \mathrm{mol}$ [65], the involved energy is significant. As an indication, the bond energy of $\mathrm{N}-\mathrm{O}$ and $\mathrm{N}=\mathrm{O}$, that are present in $\mathrm{NO}_{3}^{-}$oxyanion, correspond to 201 and $607 \mathrm{~kJ} / \mathrm{mol}$ respectively [65]. Moreover, thiocyanate anions $\left(\mathrm{SCN}^{-}\right)$were also observed to be decomposed at the nickel surface [53].

\section{Conclusions}

When comparing the shape of linear voltammograms in the presence of the investigated electrolytes, some general trends may be drawn. When the solution $\mathrm{pH}$ is such that $\mathrm{Ni}$ is not in a passive state $($ say $\mathrm{pH}<8$ ), passivity is found to be achieved only in the presence of oxyanions. In the other cases, the current density increases continuously from the beginning or after a poorly marked first maximum, so indicating that passivity has failed.
The concept of the categorization of anions helps to interpret the observed distinction in the corrosion mechanism of nickel according to the kosmotrope/chaotrope nature of the halides.

SIMS and XPS measurements performed with a representative nitrate oxyanion confirm the incorporation into the passive film of the constitutive oxygen and nitrogen atoms and with a direct bonding between nitrogen and nickel surface. The results would advocate for a decomposition process at the nickel surface during anodic polarization.

\section{Acknowledgments}

The authors are grateful to $C$. Armand, from the Département de Physique INSA Toulouse, for SIMS measurements; and to J. Esvan, from the CIRIMAT, for XPS characterizations.

\section{References}

[1] J.L. Trompette, L. Arurault, S. Fontorbes, L. Massot, Influence of the anion specificity on the electrochemical behaviour of aluminium substrates, Electrochim. Acta 55 (2010) 2901-2910. 
[2] J.L. Trompette, L. Massot, L. Arurault, S. Fontorbes, Influence of the anion specificity on the anodic polarization of titanium, Corros. Sci. 53 (2011) 12621268.

[3] J.L. Trompette, L. Massot, Chronoamperometric study of the passive behaviour of tantalum in hostile media during water addition, Corros. Sci. 57 (2012) 174181.

[4] J. Osterwald, H.H. Uhlig, Anodic polarization and passivity of $\mathrm{Ni}$ and $\mathrm{Ni}-\mathrm{Cu}$ alloys in sulfuric acid, J. Electrochem. Soc. 108 (1961) 515-519.

[5] M.L. Kronenberg, J.C. Banter, E. Yeager, F. Hovorka, The electrochemistry of nickel: II. Anodic polarization of nickel, J. Electrochem. Soc. 110 (1963) 10071013.

[6] Z. Szklarska-Smialowska, Effect of the ratio $\mathrm{Cl}^{-} / \mathrm{SO}_{4}^{2-}$ in solution on the pitting corrosion of Ni, Corros. Sci. 11 (1971) 209-221.

[7] M. Okuyama, S. Haruyama, Passive film formed on nickel in a neutral solution, Corros. Sci. 14 (1974) 1-14.

[8] B. MacDougall, M. Cohen, Anodic oxidation of nickel in neutral sulfate solution, J. Electrochem. Soc. 121 (1974) 1152-1159.

[9] G.T. Burstein, G.A. Wright, The anodic dissolution of nickel-I Perchlorate and fluoride electrolytes, Electrochim. Acta 20 (1975) 95-99.

[10] B. MacDougall, M. Cohen, Anodic oxidation films on nickel in acid solutions, J. Electrochem. Soc. 123 (1976) 191-197.

[11] A. Jouanneau, M. Keddam, M.C. Petit, A general model of the anodic behaviour of nickel in acidic media, Electrochim. Acta 21 (1976) 287-292.

[12] G.T. Burstein, G.A. Wright, The anodic dissolution of nickel-II Bromide and iodide electrolytes, Electrochim. Acta 21 (1976) 311-314.

[13] T. Dickinson, A.F. Povey, P.M.A. Sherwood, Dissolution and passivation of nickel, J. Chem. Soc. Faraday Trans. I (73) (1977) 327-343.

[14] J. Osterwald, H. Trunk, Passivity and transpassivity of nickel in fluoride electrolytes, Mater. Corros. 28 (1977) 321-325.

[15] H.H. Strehblow, B. Titze, Pitting potentials and inhibition potentials of iron and nickel for different aggressive and inhibiting anions, Corros. Sci. 17 (1977) 461-472.

[16] J.R. Vilche, A.J. Arvia, Kinetics and mechanism of the nickel electrode-II. Acid solutions containing a high of sulfate and nickel ions, Corros. Sci. 18 (1978) 441-463.

[17] H.H. Strehblow, B. Titze, B.P. Löchel, The breakdown of passivity of iron and nickel by fluoride, Corros. Sci. 19 (1979) 1047-1057.

[18] B. MacDougall, Effect of chloride ion the localized breakdown of nickel oxide films, J. Electrochem. Soc. 126 (1979) 919-925.

[19] B.P. Löchel, H.H. Strehblow, M. Sakashita, Breakdown of passivity of nickel by fluoride I. Electrochemical studies, J. Electrochem. Soc. 131 (1984) 522-529.

[20] B.P. Löchel, H.H. Strehblow, Breakdown of passivity of nickel by fluoride II. Surface analytical studies, J. Electrochem. Soc. 131 (1984) 713-723.

[21] B. MacDougall, M.J. Graham, Influence of incorporated $\mathrm{Cl}^{-}$in $\mathrm{NiO}$ on the pitting susceptibility of nickel, J. Electrochem. Soc. 131 (1984) 727-730.

[22] S.S. Abd El Rehim, S.M. Abd El Wahaab, E.A. Abd El Maguid, Electrochemical behaviour of nickel anode in $\mathrm{H}_{2} \mathrm{SO}_{4}$ solutions and the effect of halide ions, Mater. Corros. 37 (1986) 550-555.

[23] B. MacDougall, J.A. Bardwell, M.J. Graham, Effect of borate on the passivation of nickel in $\mathrm{Cl}^{-}$- containing solutions, J. Electrochem. Soc. 135 (1988) 340-342.

[24] S.G. Real, M.R. Barbosa, J.R. Viche, A.J. Arvia, Influence of chloride concentration on the active dissolution and passivation of nickel electrodes in acid sulfate solutions, J. Electrochem. Soc. 137 (1990) 1696-1702.

[25] P. Marcus, J.M. Herbelin, The entry of chloride ions into passive films on nickel studied by spectroscopic (ESCA) and nuclear $\left({ }^{36} \mathrm{Cl}\right.$ radiotracer) methods, Corros. Sci. 34 (1993) 1123-1145

[26] M.R. Barbosa, J.A. Bastos, J.J. Garcia-Jareno, F. Vicente, Chloride role in the surface of nickel electrode, Electrochim. Acta 44 (1998) 957-965.

[27] E.E. Abd El Al, S.S. Abd El Haleem, The influence of halide anions on the anodic behaviour of nickel in borate solutions, Chem. Eng. Technol. 28 (2005) 11581165

[28] S. Ahn, H. Kwon, D.D. Macdonald, Role of chloride ion on passivity breakdown on iron and nickel, J. Electrochem. Soc. 152 (2005) B482-B490.

[29] S. Ouellet, PhD Thesis, Corrosion et protection du nickel en milieux aqueux faiblement alcalins, Université Laval, Canada, 2009.

[30] S. Hinnov, J. Tamm, The effect of halide ions on nickel corrosion in perchloric acid solutions, Proc. Estonian Acad. Sci. 60 (2011) 184-192.

[31] M.A. Hopper, J.L. Ord, An optical study of the growth and oxidation of nickel hydroxide films, J. Electrochem. Soc. 120 (1973) 183-187.

[32] B. MacDougall, M. Cohen, Mechanism of the anodic oxidation on nickel, J. Electrochem. Soc. 123 (1976) 1783-1788.

[33] B. MacDougall, M. Cohen, Breakdown of oxide films on nickel, J. Electrochem. Soc. 124 (1977) 1185-1190.

[34] J.L. Ord, J.C. Clayton, D.J. de Smedt, An ellipsometric study of the anodic oxidation of nickel in neutral electrolyte, J. Electrochem. Soc. 124 (1977) $1714-1719$

[35] P. Marcus, J. Oudar, I. Olejford, XPS-study of the passive film on nickel, J. Microsc. Spectrosc. Electron. 4 (1979) 63-72.

[36] B. MacDougall, Role of oxide defects in the anodic oxidation of nickel, J. Electrochem. Soc. 127 (1980) 789-795.

[37] B. MacDougall, D.F. Mitchell, M.J. Graham, Galvanostatic oxidation of nickel in borate buffer solution. J. Electrochem. Soc. 127 (1980) 1248-1252.
[38] C.Y. Chao, Z. Szklarska-Smialowska, Ellipsometric study on the film formation of nickel in phosphate solutions, Surf. Sci. 96 (1980) 426-442.

[39] S.G. Real, J.R. Vilche, A.J. Arvia, The characteristics of the potentiodynamic potential/current profiles obtained with the $\mathrm{Ni} / 0.5 \mathrm{~N} \mathrm{H}_{2} \mathrm{SO}_{4}$ interface. A contribution to the mechanism of the electrode process, Corros. Sci. 20 (1980) 563-586.

[40] B. MacDougall, M.J. Graham, Growth of thick anodic oxide films on nickel in borate buffer solution, J. Electrochem. Soc. 128 (1981) 2321.

[41] B. MacDougall, D.F. Mitchell, G.I. Sproule, M.J. Graham, Incorporation of chloride ion in passive oxide films on nickel, J. Electrochem. Soc. 130 (1983) 543-547.

[42] B. MacDougall, D.F. Mitchell, M.J. Graham, Changes in oxide films on nickel during long-them passivation, J. Electrochem. Soc. 132 (1985) 2895-2898.

[43] V. Maurice, H. Talah, P. Marcus, A scanning tunneling microscopy study of the structure of thin oxide films grown on $\mathrm{Ni}(111)$ single crystal surfaces by anodic polarization in acid electrolyte, Surf. Sci. 304 (1994) 98-108.

[44] O.M. Magnussen, J. Scherer, B.M. Ocko, R.J. Behm, In situ X-ray scattering study of the passive film on $\mathrm{Ni}(111)$ in sulfuric acid solution, J. Phys. Chem. B 104 (2000) 1222-1226.

[45] E. Sikora, D.D. Macdonald, Nature of the passive film on nickel, Electrochim. Acta 48 (2002) 69-77.

[46] J. Scherer, B.M. Ocko, O.M. Magnussen, Structure, dissolution, and passivation of $\mathrm{Ni}(111)$ electrodes in sulfuric acid solution: an in situ STM, X-ray scattering, and electrochemical study, Electrochim. Acta 48 (2003) 1169-1191.

[47] A. Seyeux, V. Maurice, L.H. Klein, P. Marcus, Initiation of localized corrosion at the nanoscale by competitive dissolution and passivation of nickel surfaces, Electrochim. Acta 54 (2008) 540-544.

[48] B. MacDougall, M.J. Graham, Growth and stability of passive films, in: P. Marcus (Ed.), Corrosion Mechanisms in Theory and Practice, second ed., Marcel Dekker, New York, 2002, pp. 189-216 (Chapter 6).

[49] B. Beverskog, I. Puigdomenech, Revised Pourbaix diagrams for nickel at 25$300{ }^{\circ} \mathrm{C}$, Corros. Sci. 39 (1997) 969-980.

[50] K.J.R. Rosman, P.D.P. Taylor, Isotopic compositions of the elements, Pure Appl. Chem. 70 (1998) 217-235.

[51] R.J. Smith, R.E. Hummel, J.R. Ambrose, The passivation of nickel in aqueous solutions -II. An in situ investigation of the passivation of nickel using optical electrochemical techniques, Corros. Sci. 27 (1987) 815-826

[52] V.P. Grigorev, V.M. Kravchenko, I.M. Gershanova, Apparent activation energy of the anodic dissolution of nickel in sulfuric acid solutions in the presence of $\mathrm{Cl}^{-}$and $\mathrm{SCN}^{-}$ions, Protect. Met. 40 (2004) 214-219.

[53] W. Li, P.C. Pistorius, Effects of thiocyanate on the anodic dissolution of iron, chromium, nickel, and type 304 stainless steel: I. Electrochemical measurements and surface morphology, J. Electrochem. Soc. 159 (2012) C513-C518.

[54] J. Oudar, P. Marcus, Role of adsorbed sulfur in the dissolution and passivation of nickel and nickel-sulfur alloys, Appl. Surf. Sci. 3 (1979) 48-67.

[55] P. Marcus, Sulfur-assisted corrosion mechanisms and the role of alloyed elements, in: P. Marcus (Ed.), Corrosion Mechanisms in Theory and Practice, second ed., Marcel Dekker, New York, 2002, pp. 287-310 (Chapter 9).

[56] H.H. Strehblow, Mechanisms of pitting corrosion, in: P. Marcus (Ed.), Corrosion Mechanisms in Theory and Practice, second ed., Marcel Dekker, New York, 2002, pp. 243-285 (Chapter 8).

[57] V.I. Nefedov, Y.V. Salyn, G. Leonhardt, R. Scheibe, A comparison of different spectrometers and charge corrections used in X-ray photoelectron spectroscopy, J. Electron. Spectrosc. Relat. Phenom. 10 (1977) 121. reference from NIST X-ray Photoelectron Spectroscopy Database, Version 4.1 (National Institute of Standards and Technology, Gaithersburg, 2012), http:// srdata.nist.gov/xps/.

[58] J.J. Chen, N. Winograd, The adsorption and decomposition of methylamine on Pd, Surf. Sci. 326 (1995) 285-300.

[59] K. Kishi, Y. Okino, Y. Fujimoto, XPS studies of the adsorption of $\mathrm{CH}_{3} \mathrm{CN}$ and $\mathrm{C}_{6} \mathrm{H}_{5} \mathrm{CN}$ on the Ni(111) surface, Surf. Sci. 176 (1986) 23-31.

[60] K. Kishi, K. Chinomi, Y. Inoue, S. Ikeda, X-ray photoelectron spectroscopic study of the adsorption of benzene, pyridine, aniline, and nitrobenzene on evaporated nickel and iron, J. Catal. 60 (1979) 228-340.

[61] B.M. Biwer, S.L. Bernasek, Electron spectroscopic study of the iron surface and its interaction with oxygen and nitrogen, J. Electron. Spectrosc. Relat. Phenom. 40 (1986) 339. reference from NIST X-ray Photoelectron Spectroscopy Database, Version 4.1 (National Institute of Standards and Technology, Gaithersburg, 2012), http://srdata.nist.gov/xps/.

[62] S. Badrinarayanan, S. Sinha, A.B. Mandale, XPS studies of nitrogen ion implanted zirconium and titanium, J. Electron. Spectrosc. Relat. Phenom. 49 (1989) 303. reference from NIST X-ray Photoelectron Spectroscopy Database, Version 4.1 (National Institute of Standards and Technology, Gaithersburg, 2012), http://srdata.nist.gov/xps/.

[63] T.P. Hoar, D.C. Mears, G.P. Rothwell, The relationships between anodic passivity, brightening and pitting, Corros. Sci. 5 (1965) 279-289.

[64] E. McCafferty, A competitive adsorption model for the inhibition of crevice corrosion and pitting, J. Electrochem. Soc. 137 (1990) 3731-3737.

[65] S.S. Zumdahl, Chimie Générale, seconde édition, De Boeck Université, 1999, pp. 241-297 (Chapitre 6). 